\title{
Cervical Thymic Cysts-Rare Abnormality: A Report of Two Cases
}

\author{
${ }^{1}$ Ankit D Mahuvakar, ${ }^{2}$ Shaikh Mohsin Ahmed Abdul Nabi, ${ }^{3}$ Atish Balajirao Gujrathi \\ ${ }^{4}$ Vijayalaxmi Kishanrao Ambulgekar, ${ }^{5}$ Sachin Garud, ${ }^{6}$ Pradeep Khokle
}

\begin{abstract}
Cystic Lesions in the neck have a long differential diagnosis. Thymic cysts are considered rare in the cervical region, whereas they are more common in the superior mediastinal region. They may become more important diagnosis especially in the younger age group. In this article we will consider two cases, one male and other female with similar features and both being diagnosed as having cervical thymic cysts.
\end{abstract}

Keywords: Aberrant development of the thymus, Cervical thymic cysts, Cystic lesions in the neck, Ectopic thymic tissue.

How to cite this article: Mahuvakar AD, Nabi SMAA, Gujrathi AB, Ambulgekar VK, Garud S, Khokle P. Cervical Thymic CystsRare Abnormality: A Report of Two Cases. Int J Head Neck Surg 2015;6(2):90-92.

\section{Source of support: Nil}

Conflict of interest: None

\section{INTRODUCTION}

Cervical thymic masses are congenital lesions that result from aberrant thymic migration during embryogenesis. Although most of these masses are asymptomatic, they may cause debilitating symptoms secondary to encroachment on adjacent aerodigestive structures. Preoperative diagnosis of ectopic thymic tissue is rare; most cases are clinically misinterpreted as branchial cleft remnants or cystic hygromas. Definitive diagnosis has been relied on histopathologic examination in nearly all reported cases. ${ }^{1}$ Aberrant cervical solid and cystic thymic lesions have been reported in the literature and were identified at either surgery or autopsy. ${ }^{2-4}$ Nearly, two thirds of all reported cases were identified in children younger than 10 years. ${ }^{4}$ Ectopic thymic tissue in the neck is rare in patients older than 20 years. ${ }^{5}$ Heise et $\mathrm{al}^{6}$ reported

\footnotetext{
${ }^{1}$ Fellow, ${ }^{2}$ Medical Officer, ${ }^{3}$ Assistant Professor

${ }^{4}$ Professor, ${ }^{5,6}$ Resident

${ }^{1}$ Department of Skull Base Surgery, Tata Memorial Hospital Mumbai, Maharashtra, India

${ }^{2}$ Department of ENT, ENT Hospital, Mumbai, Maharashtra, India

${ }^{3-6}$ Department of ENT, Dr Shankarrao Chavan Government Medical College, Nanded, Maharashtra, India
}

Corresponding Author: Ankit D Mahuvakar, Fellow Department of Skull Base Surgery, Tata Memorial Hospital Mumbai, Maharashtra, India, Phone: 9819782717, e-mail: ankitmahuvakar@gmail.com cervical thymic cysts to be $0.3 \%$ of all congenital cervical cysts in children. We represent a series of two cases of cervical midline cystic masses, which on histopathological examination were diagnosed as cervical thymic cysts.

\section{CASE REPORTS}

\section{Case 1}

Patient is 21 years male, complaining of a painless swelling in midline neck since birth. The swelling gradually and progressively increased. No complains of difficulty in swallowing, breathing or change of voice. On examination, single well defined nontender, noninflammed swelling, in suprasternal region, not moving on swallowing or deglutition, firm in consistency, no cough impulse or pulsations, immobile, nonreducible, noncompressible (Fig. 1).

\section{INVESTIGATIONS}

- Fine needle aspiration cytology: Benign cystic lesion

- Ultrasonography of neck: cystic lesion in suprasternal region, $4 \times 3 \mathrm{~cm}$, both thyroid lobes normal.

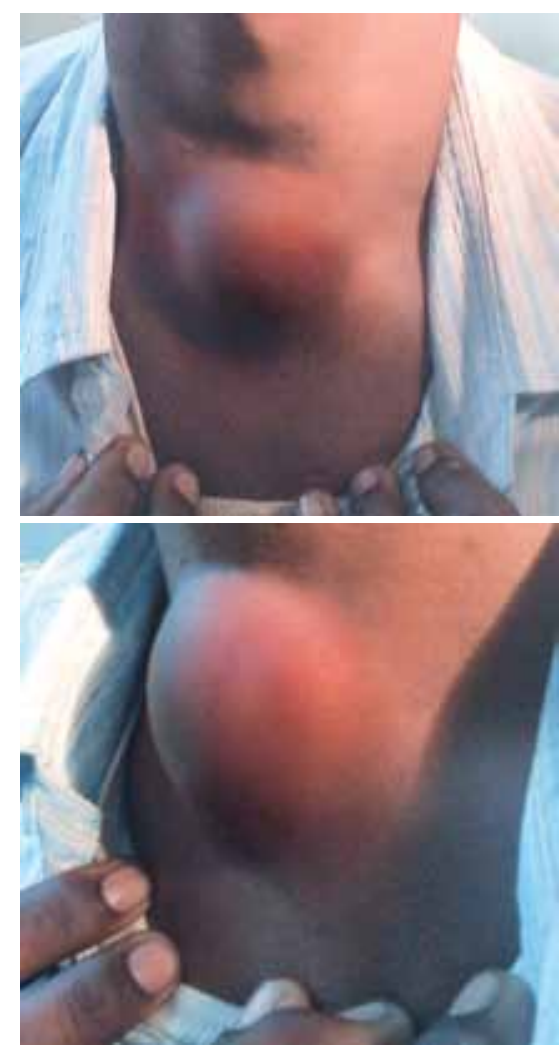

Fig. 1: Male patient showing midline neck lesion 


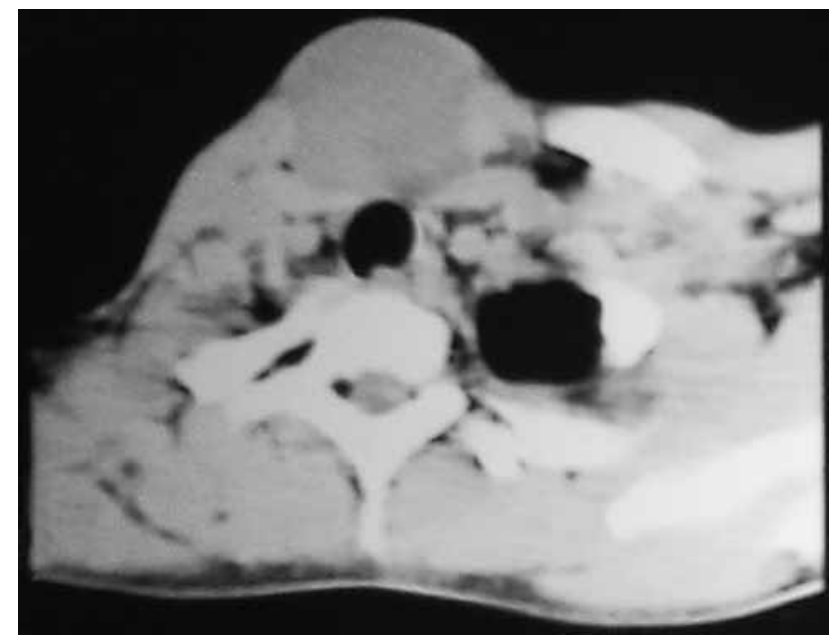

Fig. 2: Computed tomography showing the mass in midline

- Computed tomography (CT) of neck: Well defined cystic peripheral enhancing lesion measuring $4.2 \times 3.9 \mathrm{~cm}$ in midline, suprasternal region, lesion appears separate from surrounding structures, both lobes of thyroid gland and remaining structures in the neck are normal (Fig. 2).

\section{Case 2}

A female patient, 21 years old, complained of single painless swelling in midline neck since birth. Clinical examination and investigations were similar to the previous case, except the size, which was smaller (Fig. 3).

Computed tomography scan suggested single unilocular midline swelling slightly to right, measuring $3 \times 3 \mathrm{~cm}$ with substernal extension, appears free from other structures (Fig. 4).

After obtaining informed consent from patient and preanesthetic fitness, excision of the cyst was done under general anesthesia. Case 1 on operation showed midline swelling, in suprasternal region without any attachment to thyroid gland. Case 2 on operation showed swelling toward right, in suprasternal region, extending in the substernal region, with fibrous attachment to the thyroid gland. No major complications were encountered during and after the operation. Specimens were send for histopathological examination. Patients were discharged on 3rd postoperative day, followed-up on 7th day for removal of sutures. Repeat follow-up at 3 months showed no recurrence and adequate wound healing.

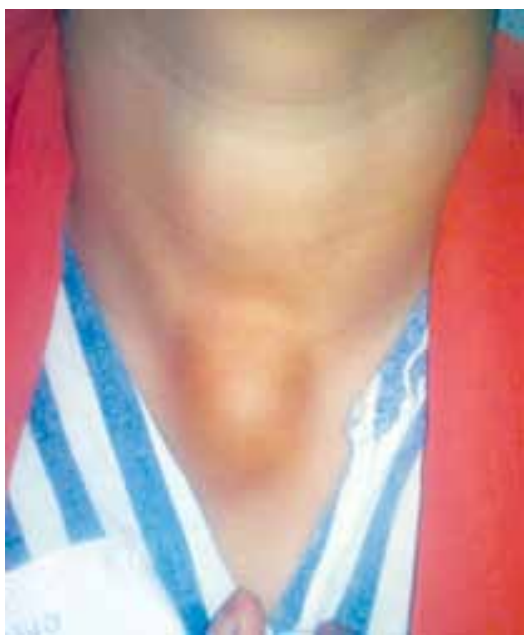

Fig. 3: Female patient showing neck mass slightly to the right

Histopathological report on both occasions showed squamous, nonkeratinized epithelium which was replaced by an inflammatory infiltrate containing numerous cholesterol clefts. The presence of thymic tissue in the walls of the cyst along with the pathognomonic presence of Hassall's corpuscules identified the thymic origin of the cyst.

\section{DISCUSSION}

Thymus gland derives its origin from the third and, in some instances, the fourth pharyngeal pouch; it develops bilaterally early in fetal life and descends down the neck during the sixth to eighth week of gestational life, where the two primordia fuse to form the gland, which then reaches its definitive position in the mediastinum, behind the sternum. Clinically, in most cases, ectopic thymic tissue presents as a unilateral, asymptomatic neck mass, commonly in the left side of the neck. ${ }^{7-10}$ Thymus gland reaches its relative maximum size in children aged 2 to 4 years, attaining its final size at puberty when it weighs 30 to $40 \mathrm{gm}$. The gland then involutes and is replaced by fibro fatty tissue.

The pathogenesis of the ectopic thymus has not been fully clarified yet. Several theories have been proposed, including the following:

- Complete or partial failure of the unilateral gland to migrate to its normal position. The presence of parathyroid gland in the mass supports the idea of

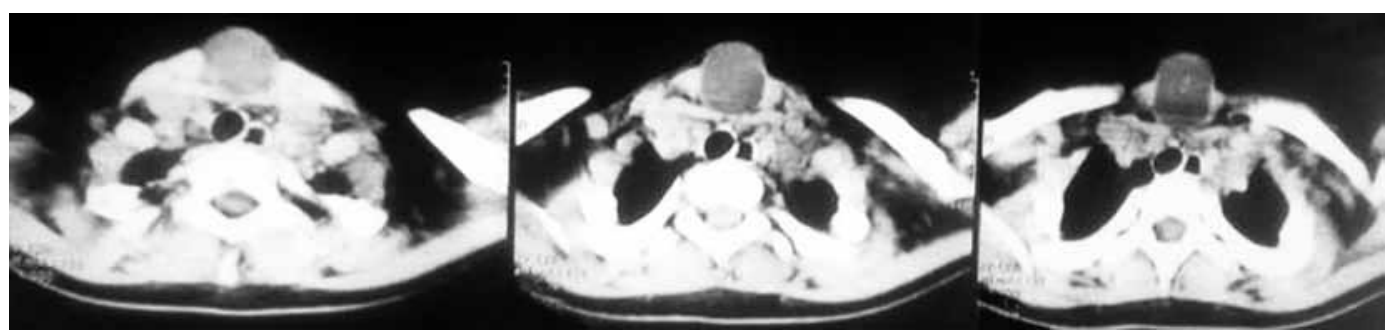

Fig. 4: Computed tomography scan showing the same mass 
nondescending tissue. ${ }^{11,12}$ Also, the fact that aberrant thymus is usually found in the normal pathway that the gland follows for its descent to the thorax is in favor of this theory.

- Sequestration of accessory cervical foci along the normal pathway of descent. In that case, there would be normal thymic tissue in the mediastinum, as most of it would have migrated. ${ }^{13}$

- Ectopic thymic gland, in the form of masses located in the pharynx, the trachea or the base of the skull. ${ }^{14}$

- Failure, after descent of the majority of the gland, of rostal fragments to involute, leading to separate accessory lobes or cords.

There are two theories about the pathogenesis of a thymic cyst as follows:

- Relates it to acquired progressive cystic degeneration of Hassall's corpuscles, of unknown etiology.

- Cystic changes in persistent unincorporated remnants of the thymopharyngeal duct.

According to Speer, it may be due to embryological remnants in the neck, sequestration products in pathological involution, neoplastic process, degeneration of Hassall's bodies, mesenchymal elements. ${ }^{15}$

These lesions usually lie medial to the sternocleidomastoid muscle, anterior to the carotid sheath and lateral to the thyroid gland. Preoperative CT and chest X-ray should be obtained to confirm the presence of normal or abnormal thymic tissue before surgery for suspected CTC. Intact complete surgical removal of the CTC is the treatment of choice, bearing in mind that it may be adherent to the surrounding structures, such as the vagus nerve, the internal jugular vein, and carotid artery as well as the phrenic, hypoglossal and recurrent laryngeal nerves. About $50 \%$ of CTCs may have a fibrous connection to normal thymic tissue or active thymic cells, and removal of the duct may leave the patient athymic.
This is not a problem in an adult, but a child may develop immunodeficiency problems.

\section{REFERENCES}

1. Tunkel DE, Erozan YS, Weir EG. Ectopic cervical thymic tissue, diagnosed by fine needle aspiration cytology. Arch Pathol Lab Med 2001;125:278-281.

2. Nguyen Q, de Tar M, Wells W, Corbett D. Cervical thymic cyst: case reports and review of the literature. Laryngoscope 1996;106:247-252.

3. Loney DA, Bauman NM. Ectopic cervical thymic masses in infants: a case report and review of the literature. Int J Pediatr Otorhinolaryngol 1998;43:77-84.

4. Millman B, Pransky S, Castillo J, Zipfel T, Wood WE. Cervical thymic anomalies. Int J Pediatr Otorhinolaryngol 1999;47: 29-39.

5. Bieger RC, McAdams AJ. Thymic cysts. Arch Pathol 1966;82: 535-541.

6. Heise YY, Hsue 1. S, Lin JN, et al. Pathological analysis of congenital cervical cysts in children: 20 years of experience at Chang Gung Memorial Hospital. Chang Guang Med J 2003; 26:107-113.

7. Rypens F, Avni F, Muller F, Baran D, Struyven J. Thymus ectopique cervical. J Radiol 1989;70:721-723.

8. Domarus H, Blaha I. Ecotopic thymus in the neck: a case report and review of the literature. Br J Plast Surg 1978;40: 532-535.

9. Tien Lau H, Barlow B, Gahndi RP. Ectopic thymus: presenting as neck mass. J Pediatr Surg 1984;19:197.

10. Lewis CT. Ectopic thymus of the neck-report of three examples in children. Postgrad Med J 1975;51:38-40.

11. Tovi F, Mares AJ. The aberrant cervical thymus: embryology, pathology and clinical implications. Am J Surg 1978;136:631-637.

12. Zarbo RJ, Areen RG, McClatchey KD, Baker SB. Thymopharyngeal duct cyst: a form of cervical thymus. Ann Otol Laryngol 1983;92:284-289.

13. Spingland N, Bensoussan AL, Blanchard H, Russo P. Aberrant cervical thymus in children: three case reports and review of the literature. J Pediatr Surg 1990;25:1196-1199.

14. Lewis MR. Persistence of the thymus in the cervical area. J Pediatr 1962;61:887-893.

15. Speer FD. Thymic cysts. NY Medical College Flower Hospital Bulletin 1938;1:142-150. 